\title{
Fifteen Years (1993-2007) of Surface Freshwater Storage Variability in the Ganges-Brahmaputra River Basin Using Multi-Satellite Observations
}

\author{
Edward Salameh ${ }^{1,2}$, Frédéric Frappart ${ }^{1,3}$, Fabrice Papa ${ }^{1,4, *}$, Andreas Güntner ${ }^{5}$, \\ Vuruputur Venugopal ${ }^{6}$, Augusto Getirana ${ }^{7,8}$, Catherine Prigent ${ }^{9}$, Filipe Aires ${ }^{9}$, David Labat ${ }^{3}$ \\ and Benoît Laignel ${ }^{2}$
}

1 Laboratoire d'Etudes en Géophysique et Océanographie Spatiales (LEGOS), Université de Toulouse, IRD, CNES, CNRS, UPS, Toulouse 31400, France; edward.salameh@legos.obs-mip.fr (E.S.); frederic.frappart@legos.obs-mip.fr (F.F.)

2 Université de Rouen, UMR CNRS 6143, Mont-Saint-Aignan 76821, France; benoit.laignel@univ-rouen.fr

3 Géosciences Environnement Toulouse (GET), Université de Toulouse, IRD, CNES, CNRS, UPS, Toulouse 31400, France; david.labat@get.omp.eu

4 Indo-French Cell for Water Sciences (IFCWS), IRD-IISc-NIO-IITM Joint International Laboratory, Bangalore 560012, India

5 GFZ German Research Centre for Geosciences, Potsdam 14473, Germany; andreas.guentner@gfz-potsdam.de

6 Centre for Atmospheric and Oceanic Sciences (CAOS), Indian Institute of Science, IISc, Bangalore 560012, India; venu@caos.iisc.ernet.in

7 Hydrological Sciences Laboratory, NASA Goddard Space Flight Center, Greenbelt, MD 20771, USA; augusto.getirana@nasa.gov

8 Earth System Science Interdisciplinary Center, University of Maryland, College Park, College Park, MD 20742, USA

9 Laboratoire d'Etudes du Rayonnement et de la Matière en Astrophysique (LERMA), CNRS, Observatoire de Paris, Paris 75014, France; Catherine.Prigent@obspm.fr (C.P.); filipe.aires@obspm.fr (F.A.)

* Correspondence: fabrice.papa@ird.fr; Tel.: +91-776-0860-411

Academic Editor: Karl-Erich Lindenschmidt

Received: 9 February 2017; Accepted: 25 March 2017; Published: 31 March 2017

\begin{abstract}
Surface water storage is a key component of the terrestrial hydrological and biogeochemical cycles that also plays a major role in water resources management. In this study, surface water storage (SWS) variations are estimated at monthly time-scale over 15 years (1993-2007) using a hypsographic approach based on the combination of topographic information from Advance Spaceborne Thermal Emission and Reflection Radiometer (ASTER) and Hydrological Modeling and Analysis Platform (HyMAP)-based Global Digital Elevation Models (GDEM) and the Global Inundation Extent Multi-Satellite (GIEMS) product in the Ganges-Brahmaputra basin. The monthly variations of the surface water storage are in good accordance with precipitation from Global Precipitation Climatology Project (GPCP), river discharges at the outlet of the Ganges and the Brahmaputra, and terrestrial water storage (TWS) from the Gravity Recovery And Climate Experiment (GRACE), with correlations higher than 0.85 . Surface water storage presents a strong seasonal signal ( $\sim 96 \mathrm{~km}^{3}$ estimated by GIEMS/ASTER and $\sim 378 \mathrm{~km}^{3}$ by GIEMS/HyMAPs), representing $\sim 51 \%$ and $\sim 41 \%$ respectively of the total water storage signal and it exhibits a large inter-annual variability with strong negative anomalies during the drought-like conditions of 1994 or strong positive anomalies such as in 1998. This new dataset of SWS is a new, highly valuable source of information for hydrological and climate modeling studies of the Ganges-Brahmaputra river basin.
\end{abstract}

Keywords: Ganges-Brahmaputra; surface water storage; multi-satellite; floodplains 


\section{Introduction}

Continental freshwater is crucial for all forms of life. Despite their minor quantitative contribution to the total water storage on Earth $(<1 \%)$, surface water stored in rivers, lakes, wetlands, floodplains and even man-made reservoirs plays a major role in climate variability, also affecting biogeochemical and trace gas cycles. As a part of the hydrologic cycle, investigating the spatio-temporal variation of the surface water storage (SWS) is fundamental to the study of the global water cycle while providing a critical parameter for water resources management [1].

Until recently, our knowledge of surface water dynamics relied on sparse in situ observations and hydrological models. Traditional in situ gauge measurements quantify the water discharge in river channels, but no information is provided by these measurements regarding the diffusive flow over floodplains associated to rivers or wetlands. Furthermore, the number of gauging networks is, in general, limited especially in remote areas with difficult access such as tropical regions. When available, discharge data and hydrological observations are often classified by governments due to transboundary issues and their access is restricted for scientific usage [2,3].

The ability to estimate SWS variability at large scales is becoming increasingly important because of the need to predict the availability of freshwater resources and also to link this variability to climate change and extreme events such as droughts and floods [4]. Recent advancements in remote sensing made the study of surface water dynamics possible at regional to global scale [3]. Multi-satellite remote sensing techniques now offer important information on land surface waters, such as the variations of surface water extents at the global scale [2,5,6] provided by the Global Inundation Extent from Multi-Satellites (GIEMS). This information is complementary to radar altimetry observations that systematically monitor the water levels in lakes, large rivers, wetlands and floodplains [7,8].

Recent efforts have been undertaken to quantify the surface freshwater storage and its variations at seasonal to inter-annual time scales using satellite observations. A technique developed by [9] to estimate SWS variations combines surface water extent observations with altimeter-derived height variations in rivers, wetlands, and inundations [10]. This technique was firstly developed over the Rio Negro, a sub-basin of the Amazon [9], and it was tested over the $\mathrm{Ob}$ River basin [11] and the Orinoco [12]. Over the Amazon [4], SWS variations over the period 2003-2007 helped to quantify and characterize the extreme drought of 2005. Over the Ganges-Brahmaputra River system [13], SWS obtained from a combination of GIEMS and ENVISAT observations helped to map sub-surface water variations by decomposing the total terrestrial water storage (TWS) variations measured by the Gravity Recovery And Climate Experiment (GRACE).

Another technique to estimate SWS was proposed by [14], and combines surface water extents from GIEMS with topographic data derived from Global Digital Elevation Model (GDEM), using a hypsographic curve approach. The latter technique was firstly developed and assessed over the Amazon watershed [14] and helped to characterize the SWS anomaly during the 1997 and 2005 extreme droughts.

In the present study, we propose to estimate and analyze SWS variations over the Ganges-Brahmaputra (GB) system using the hypsographic curve technique proposed by [14]. The GB system drains a large part of the Indian sub-continent and hosts more than 700 million people. It is the third largest freshwater outlet to the world's oceans, being exceeded only by the Amazon and the Congo drainage basins [15]. The basin is facing strong climate variability with alternate periods of floods and droughts. Due to the population growth, the excessive use of water for industrial and agricultural purposes, many water management challenges are emerging in this region [16]. The Indian sub-continent is facing acute shortages of drinking and agricultural water supply, aggravated by geogenic arsenic contamination of groundwater reservoirs, especially in Bangladesh [17].

Sections 2 and 3 present respectively the study domain and the datasets used in this study. In Section 4, we briefly describe the SWS estimation technique [14]. The results are presented and discussed in Section 5; an evaluation is performed by comparing the new estimates with SWS estimates provided by the GIEMS-ENVISAT combination technique [13], as well as other external datasets 
such as GRACE-derived TWS variations, satellite altimetry-derived river discharge observations and precipitation. Conclusions and perspectives are provided in Section 6.

\section{Study Area}

The Ganges-Brahmaputra-Meghna (hereafter referred to as the Ganges-Brahmaputra basin or GB) is a transboundary river system draining a large area of $\sim 1.7$ million $\mathrm{km}^{2}$ and crossing India, China, Nepal, Bhutan, and Bangladesh (Figure 1).

The headwaters of the Ganges $(\mathrm{G})$ and Brahmaputra (B) Rivers originate in the Himalayan range in China. The Ganges heads in the Gangotri glacier whilst the Brahmaputra River head is located in the southern slopes of Kailash Mountain in the Trans-Himalaya [15]. After flowing southwest into India and then turning southeast, the Ganges River converges with Brahmaputra in Bangladesh and flow into the Bay of Bengal where the GB delta is formed. Before merging with the Ganges, the Brahmaputra River flows east through the southern area of China, then flows south into eastern India and turns southwest crossing Bangladesh borders. The Ganges watercourse is classed as a meandering channel while Brahmaputra is a braided one $[18,19]$.

The GB River basin is unique in the world in terms of its climate and great availability of freshwater that is highly seasonal and driven primarily by monsoonal rainfall that dominates discharge, with a lesser contribution from snowmelt [15].

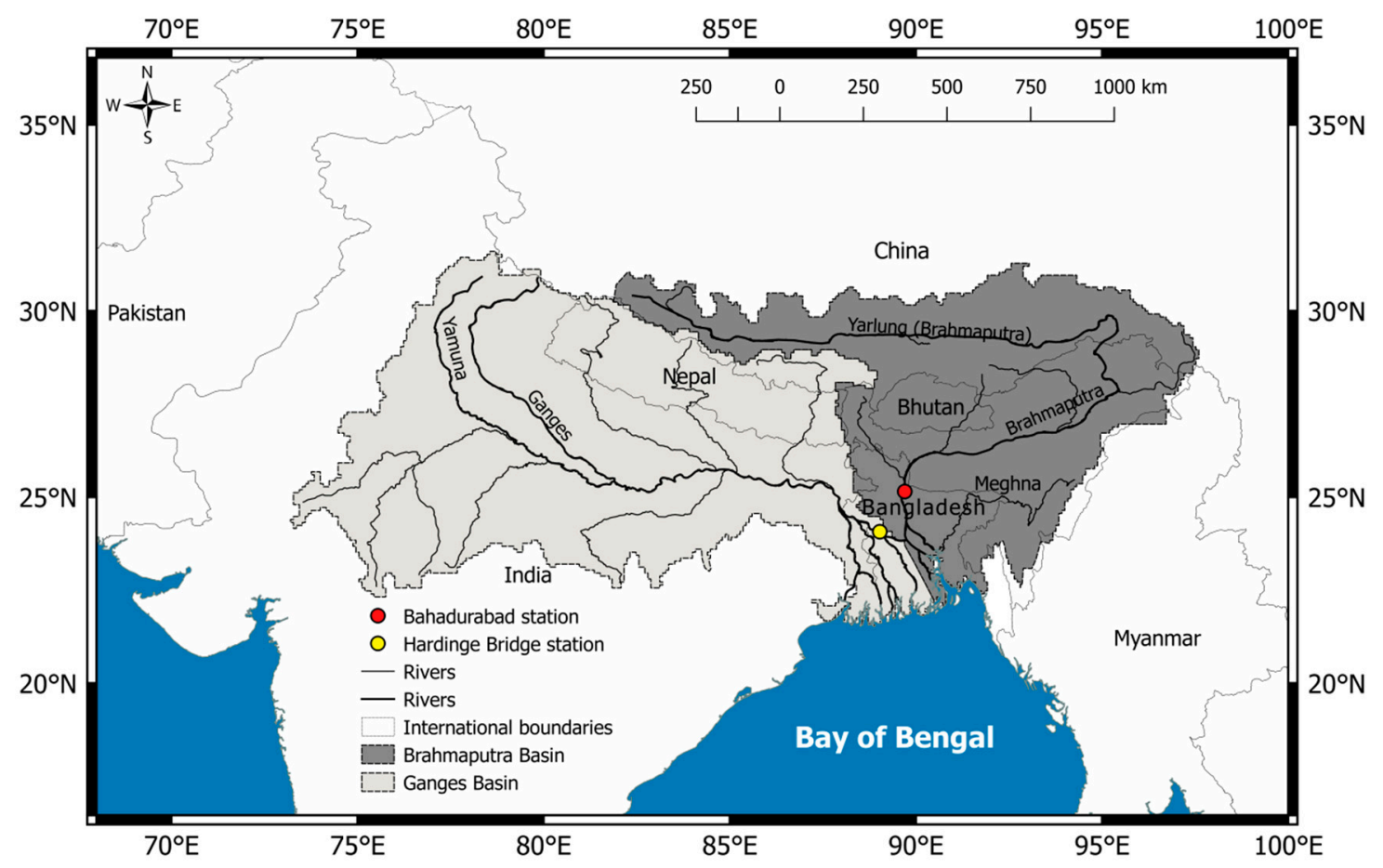

Figure 1. Ganges and Brahmaputra River basin, with the respective catchment areas shown in light gray (Ganges) and dark gray (Brahmaputra). The black lines show the main rivers (thick line) and associated tributaries (thin line) hydrography. Political borders are shown in a gray line. The red and the yellow circles correspond to the locations of Bahadurabad and Hardinge Bridge in situ gauging stations respectively where altimeter-derived river discharges are estimated.

\section{Datasets}

\subsection{Global Inundation Extent from Multi-Satellites (GIEMS)}

The complete methodology that captures the extent of episodic and seasonal inundation, wetlands, rivers, lakes and irrigated agriculture, at the global scale, is described in detail in $[2,5,6,20,21]$. 
The technique uses a complementary suite of satellite observations covering a large wavelength range: (1) passive microwave emissivities between 19 and $85 \mathrm{GHz}$. These are estimated from the Special Sensor Microwave/Imager (SSM/I) observations by removing the contributions of the atmosphere (water vapor, clouds, rain) and the modulation by the surface temperature [22,23]. The technique uses ancillary data from the International Satellite Cloud Climatology Project (ISCCP) [24] and the National Centers for Environment Prediction (NCEP) reanalysis [25]; (2) Advanced Very High Resolution Radiometer (AVHRR) visible $(0.58-0.68 \mu \mathrm{m})$ and near-infrared $(0.73-1.1 \mu \mathrm{m})$ reflectances and the derived Normalized Difference Vegetation Index (NDVI); (3) backscatter at $5.25 \mathrm{GHz}$ from the European Remote Sensing (ERS) satellite scatterometer.

Observations are averaged over each month and mapped to an equal area grid of $0.25^{\circ}$ resolution at the equator (each pixel covers $773 \mathrm{~km}^{2}$ ) [2,6]. An unsupervised classification of the three sources of satellite data is performed and the pixels with satellite signatures likely related to inundation are retained. For each inundated pixel, the monthly fractional coverage by open water is obtained using the passive microwave signal and a linear mixture model with end-members calibrated with scatterometer observations to account for the effects of vegetation cover [6,20]. As the microwave measurements are also sensitive to the snow cover, snow and ice masks are used to filter the results and avoid any confusion with snow-covered pixels [2]. Because the ERS scatterometer encountered serious technical problems after 2000, the processing scheme had to be adapted to extend the dataset and monthly mean climatology of ERS and NDVI-AVHRR observations are used [2,5]. Fifteen years of global monthly water surfaces extent for the period 1993-2007 are available [5]. This dataset has been extensively evaluated at the global scale $[2,6,26]$ and for a wide range of environments $[9,21,27,28]$. It has also been used for climatic and hydrological analyses, such as the evaluation of methane surface emissions models $[29,30]$ and the validation of the river flooding schemes coupled with land surface models [31-35].

The spatial distribution of GIEMS was evaluated against high-resolution (100 m) SAR images in [6] and in [36] over the Amazon basin leading to an overall GIEMS uncertainty of $\sim 10 \%$ for GIEMS. Over the Indian Sub-Continent (and especially GB), the spatial distribution of GIEMS was evaluated against static surface water dataset (Global Lake and Wetland Dataset, GLWD-3, [37]) and other related hydrological variables (precipitation, altimeter-derived river heights, river discharge) in $[5,21]$, as well as using other regional surveys representing various components of wetland and open-water distributions [38].

Figure 2 shows GIEMS characteristics over the GB basin. Figure 2a,c show the annual mean and annual maximum extent of surface water respectively, averaged over 15 years (180 months). They exhibit very realistic distributions of major rivers (Ganges-Brahmaputra-Meghna River systems) and their tributaries and distributaries. Associated inundated areas, wetlands and the region of the Bengal delta are well delineated even in the presence of complex areas characterized by extensive flooding. The associated standard deviations (Figure $2 \mathrm{~b}$ ) show relatively high values $(<50 \%)$, illustrating the high seasonal and inter-annual variability of hydrologic processes within the GB system. This is also shown in Figure $2 \mathrm{~d}$ where the mean amplitude of the water extent (difference between the mean maximum and the mean minimum over the record for each pixel) exhibits very high values. It should be noted here that despite the fact that GIEMS is able to capture the distributions and variations of surface freshwater in the GB basin, some very high maximum values of surface water extents (Figure 2c) could be related to the fact that the method encounters difficulties in some regions to discriminate between very saturated/moist soil and standing open water, especially in the delta region. This can lead to an overestimation of the actual surface water extents, especially for pixels with high flood coverage (see the histograms in Figure 2d of [2]). 


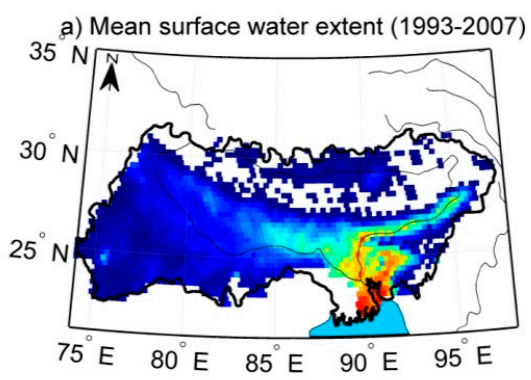

c) Surface water extent mean annual maximum

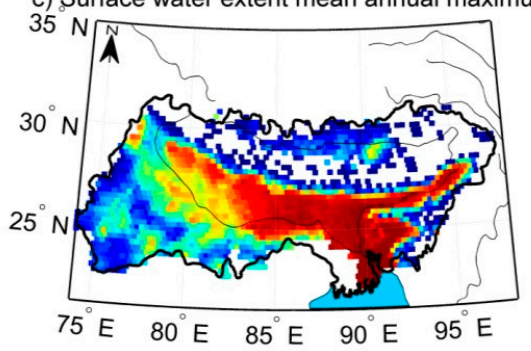

b) Surface water extent standard deviation (1993-2007)

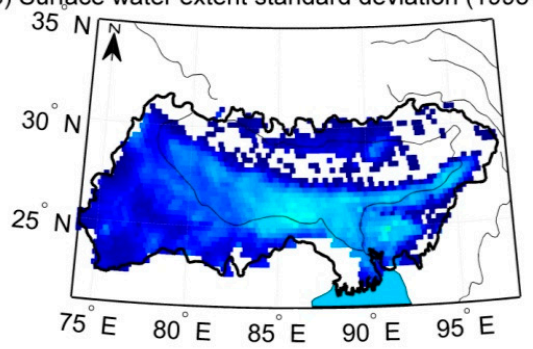

d) Surface water extent mean annual amplitude

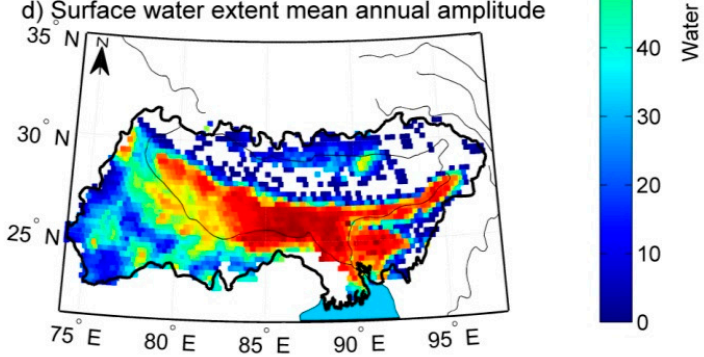

Figure 2. Main characteristics of the spatial distribution of the surface water extents provided by Global Inundation Extent Multi-Satellite (GIEMS) for the Ganges-Brahmaputra (GB) basin (all values as areal fractions of $773 \mathrm{~km}^{2}$ GIEMS cells): (a) Mean surface water extent for the 1993-2007 period;

(b) Associated standard deviation; (c) Mean annual maximum; (d) Mean annual amplitude.

\subsection{ASTER-GDEM to Derive Hypsographic Curves}

Advanced Spaceborne Thermal Emission and Reflection Radiometer (ASTER) GDEM was developed jointly by the National Aeronautic and Space Administration (NASA) and the Ministry of Economy, Trade and Industry (METI) of Japan. The ASTER instrument, launched onboard NASA's Terra spacecraft in December 1999, has an along-track stereoscopic capability using its near infrared spectral band and its nadir-viewing and backward-viewing telescopes to acquire stereo image data with a base-to-height ratio of 0.6. The basic characteristics of stereoscopy and its application to the ASTER system for GDEM generation are explained in detail in [39]. The horizontal spatial resolution is $15 \mathrm{~m}$ and one nadir-looking ASTER visible and near-infrared (VNIR) scene corresponds to $60 \mathrm{~km}^{2}$. The methodology used to produce the ASTER GDEM involves automated processing of the entire 1.5-million ASTER scenes archived from the start of observation until August 2008 [39,40]. The processing includes stereo-correlation to produce $\sim 1,264,000$ individual scene-based ASTER DEMs, cloud masking to remove cloudy pixels, stacking all cloud-screened DEMs removing residual bad values and outliers, averaging selected data to create final pixel values, and then correcting residual anomalies. The ASTER-GDEM covers land surfaces between $83^{\circ} \mathrm{N}$ and $83^{\circ} \mathrm{S}$ and is partitioned into 22,600 tiles of $1^{\circ} \times 1^{\circ}$ (containing at least $0.01 \%$ of land area). ASTER-GDEM has a $1^{\prime \prime}(30 \mathrm{~m})$ spatial horizontal resolution and is referenced with respect to the WGS84/EGM96 geoid. Several studies have dealt with the evaluation of ASTER-GDEM at local to regional scales [41-44]. Pre-production accuracies for the global product were estimated at $\sim 20 \mathrm{~m}$ vertically and $\sim 30 \mathrm{~m}$ horizontally. In this study, we use the ASTER-GDEM Version 2 released in October 2011 [45].

\subsection{SRTM-GDEM to Derive Hypsographic Curves as Used in CaMa-Flood and HyMAP Models}

The SRTM (Shuttle Radar Topography Mission) [46] mission is a joint effort between the NASA, the National Geospatial Intelligence Agency (NGA), the German (Deutsches Zentrum für Luft-und Raumfahrt) and the Italian (Agenzia Spaziale Italiana) spatial agencies. The instruments of SRTM mission embarked on Endeavour in February 2000 and acquired radar data during its 11-day mission which allows the construction of a GDEM of all land surfaces between $60^{\circ} \mathrm{N}$ and $56^{\circ} \mathrm{S}$ [46]. In this study, we use SRTM30 DEM modulated (error correction) as in [47] (CaMa-Flood) and [33] 
(HyMAP). See [48] for a detailed description of error corrections and the construction of SRTM-derived hypsographic curves.

\subsection{Complementary Datasets Used for Validation}

\subsubsection{Multi-Satellite Surface Water Storage from GIEMS and ENVISAT Radar Altimeter}

Maps of water levels over the floodplains of the Ganges-Brahmaputra basin were obtained by combining observations from GIEMS and altimetry-based water levels at monthly time-scale over the 2003-2007 period where all the datasets overlap [13]. Water levels for 58 ENVISAT RA-2 altimetry stations were interpolated with respect to the inverse of the distance from the gridpoint over inundated surfaces from GIEMS [2,5]. Each monthly map of surface water levels has a spatial resolution of $0.25^{\circ}$ and is referenced to the EGM2008 geoid [49]. The error on these estimates is lower than $10 \%$ [13]. A map of minimum water levels was estimated for the entire observation period using a hypsometric approach to take into account the difference of altitude between the river and the floodplain (see $[12,13]$ for more details). This dataset is made available by the Centre de Topographie des Océans et de l'Hydrosphère (CTOH) [50].

\subsubsection{GRACE Level-2 Monthly Solutions}

The Gravity Recovery And Climate Experiment (GRACE) mission, launched in March 2002, provides measurements of the spatio-temporal changes in Earth's gravity field. At basin scale, GRACE data can be used to derive the monthly changes of the total land water storage (TWS) $[51,52]$ with an accuracy of $\sim 1.5 \mathrm{~cm}$ of equivalent water thickness when averaged over surfaces of a few $100 \mathrm{~km}^{2}$ [53]. Three processing centers, including the Center for Space Research (CSR), Austin, TX, USA, the German Research Centre for Geosciences (GFZ), Potsdam, Germany, the Jet Propulsion Laboratory (JPL), Pasadena, CA, USA, and the Science Data Center (SDC) are in charge of the processing of the GRACE data and the production of Level-1 and Level-2 solutions. Level-2 solutions consist of time series of monthly averages of Stokes coefficients (i.e., dimensionless spherical harmonics coefficients of geopotential) developed up to a degree between 90 and 150 that are adjusted from along-track inter-satellite range GRACE measurements. These coefficients are mostly related to water storage variations on land. In this study, we use the Level-2 Release 05 solutions. The presence of an unrealistic high frequency noise corresponding to north-south striping is caused by orbit resonance during the Stokes coefficients determination and aliasing of poorly modeled short-term phenomena. To attenuate the noise in the Level-2 GRACE solutions, we applied an Independent Component Analysis (ICA) approach to the combination of GFZ/UTCSR/JPL solutions of the same monthly period to isolate statistically independent components of the observed gravity field (i.e., the continental water storage contribution from the high frequency noise) $[54,55]$.

\subsubsection{GPCP Monthly Rainfall Product}

In order to further evaluate our various estimates of the satellite-derived surface water storage, we will compare them with precipitation over the Ganges and Brahmaputra watersheds estimated by the Global Precipitation Climatology Project (GPCP). GPCP, established in 1986 by the World Climate Research Program, quantifies the distribution of precipitation over the globe [56]. We use the Satellite-Gauge Combined Precipitation Data product of GPCP Version 2.1 data (monthly means from 1993 to 2008) with a spatial resolution of $2.5^{\circ}$ in latitude and longitude. Over land surfaces, the uncertainty in the rate estimates from GPCP is generally lower than over the oceans due to the in situ gauge input (in addition to satellite) from the GPCC (Global Precipitation Climatology Center). Over land, validation experiments have been conducted in a variety of locations worldwide and the results suggest that, while there are known problems in regions of persistent convective precipitation, non-precipitating cirrus or regions of complex terrain, the estimated uncertainties range between $10 \%$ and $30 \%$ [56]. 


\subsubsection{River Discharges}

In situ river water level and discharge are infrequently recorded by the Bangladesh Water Development Board (BWDB) [57] at the two basin outlet stations before the confluence of the two rivers, at the Hardinge Bridge station $\left(24.07^{\circ} \mathrm{N} ; 89.03^{\circ} \mathrm{E}\right)$ for the Ganges and the Bahadurabad station $\left(25.15^{\circ} \mathrm{N} ; 89.70^{\circ} \mathrm{E}\right)$ for the Brahmaputra (Figure 1). Here, we will use the discharge for each river derived from satellite altimeter as in [58] for the 1993-2007 period.

\section{Methods}

\subsection{GIEMS Surface Water Extent Thresholding}

Previous analysis $[2,21,38]$ suggested that GIEMS overestimates the actual surface water extents in regions of very saturated soils. To overcome this issue, we use external information on flood coverage from the Dartmouth Flood Observatory (DFO) database that provides surface water extent for the period 2002-2015 [59]. It comprises the Surface Water Record (SWR), a comprehensive record of satellite-observed changes in the Earth's inland surface waters, compiled from the flooding history over the period 2002-2015. Extent of surface water is mostly derived from NASA MODerate-resolution Imaging Spectroradiometer (MODIS) Terra and Aqua sensors with, in some cases, additional information from Radarsat, ASTER, or other higher spatial resolution data [60]. Water areas are accumulated over 10 days to minimize the effect of cloud cover. Inundation maps are made available at a spatial resolution of $250 \mathrm{~m}$ on $10^{\circ} \times 10^{\circ}$ tiles. A color code indicates maximum flood extent each year. This dataset is commonly used for estimating flood extent limits when processing other remotely sensed observations (e.g., [13,61,62]). It was resampled on the GIEMS low resolution grid providing a percentage of inundation for each grid point equal to the inundation extent given by the SWR divided by the area of the GIEMS grid element $\left(773 \mathrm{~km}^{2}\right)$. The resulting MODIS inundation mask over the Ganges-Brahmaputra is presented in Figure 3. One can see that the main river channels, along with the major floodplains and wetlands are well depicted over the basin. However, compared to GIEMS estimates (Figure 2), many pixels present lower maximum extents, especially in the upstream regions.

In the following, the DFO MODIS-derived inundation map is used to create an inundation mask in order to limit the surface water extent given by GIEMS over the Ganges-Brahmaputra. For each pixel of GIEMS, monthly surface water extent $\operatorname{S}_{\text {GIEMS }}(\boldsymbol{\alpha}, \boldsymbol{t})$ is modulated by multiplying it by the ratio of maximum inundation extent of MODIS $S_{\text {MODIs }}(\alpha)$ and the maximum monthly extent value of GIEMS over the record such as:

$$
S_{\mathrm{GIEMS}}(\alpha, t)=S_{\mathrm{GIEMS}}(\alpha, t) \times \frac{S_{\mathrm{MODIS}}(\alpha)}{\max \left(S_{\mathrm{GIEMS}}\left(t_{i=1, \ldots, 180}\right)\right)}
$$

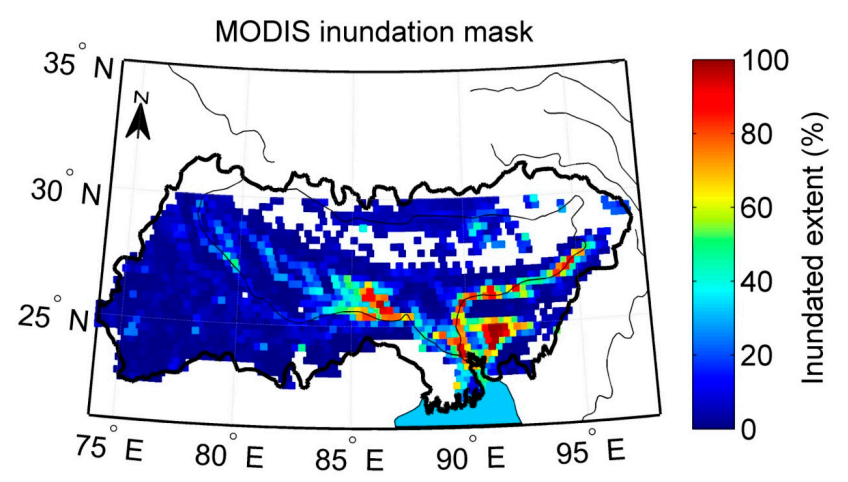

Figure 3. MODerate-resolution Imaging Spectroradiometer (MODIS)-derived surface water extent (MODIS inundation extent mask in the followings) over the GB system given in percentage of the pixel area. 


\subsection{The Hypsographic Curve Approach}

The method to estimate surface freshwater storage consists in the combination of the surface water extent from GIEMS product with a global digital elevation model (GDEM), using a hypsographic curve approach that relates the flooded area to the elevation. We will derive here two estimates using two global datasets of hypsographic curves derived from ASTER-GDEM and SRTM30 DEM (simply named as HyMAP in the following) as processed for CaMa-Flood and HyMAP models. The three-step methodology to construct the hypsographic curve and estimate SWS is described in details in [14], and is briefly summarized below:

1. The first step is to construct the hypsographic curve for each pixel of the surface water extent dataset (GIEMS). The corresponding GDEM elevation points for each pixel of GIEMS product (equal-grid of $773 \mathrm{~km}^{2}$ ) are selected. The elevation distribution function is then created and converted (by integration) to a curve of cumulative frequencies. The latter function presents the so-called hypsographic curve that consists of an area-elevation relationship, constructed for each pixel of the GIEMS data set.

2. In the second step, a translation is applied to set to zero the lowest elevation of the hypsographic curve by subtracting the lowest value from all other elevations. The hypsographic curve is then converted into an area-surface water volume relationship by estimating the surface water volume associated with an increase of the pixel fractional open water coverage by filling the hypsographic curve from its base level to an upward level, following [13]:

$$
V(\alpha)=\sum_{i=1}^{\alpha}(h(i)-h(i-1)) \times \frac{S}{100} \times i
$$

where $V$ is the surface water volume $\left(\right.$ in $\mathrm{km}^{3}$ ) for a percentage of flood/inundation $\alpha$ (an increment $i$ of $1 \%$ in percentage of inundation is chosen), $S$ is the area of a GIEMS pixel $\left(773 \mathrm{~km}^{2}\right)$, and $h$ the elevation (in $\mathrm{km}$ ) for a percentage of flood/inundation $\alpha$ given by the hypsographic curve.

3. In the last step, the surface water storage of each pixel is estimated for each month by combining the hypsographic curve with the monthly variations of surface water extent from GIEMS using Equation (2). The estimated surface water storages are not absolute. They correspond to the water volume present over a reference surface that is the topography or the elevation of the surface corresponding to the minimum water levels during the observation period. Thus, the estimated water storage represents the increment above the minimum storage.

Examples of hypsographic curves at several locations in the GB basin are shown in Figure 4.

One can see that, in most cases, the hypsographic curves from ASTER-GDEM and STRM30-HyMAP are very similar (Figure $4 \mathrm{c}, \mathrm{h}, \mathrm{i}, \mathrm{l}, \mathrm{o}$ ) or showing small differences of less than few $\mathrm{km}^{3}$ (Figure $4 \mathrm{a}, \mathrm{b}, \mathrm{j}, \mathrm{n}, \mathrm{p}$ ). In some cases, the differences are large (Figure 4e,g). Those differences can be attributed to the raw DEM product specificities (mode of acquisition, resolution, uncertainties, and errors). Indeed, both DEMs have been estimated with extremely different techniques (SRTM-30 is based on radar observations while ASTER-GDEM is made using near infrared spectral band). Moreover, one of the major limitations of satellite-derived DEMs is that they are not always representing bare earth but can include vegetation and man-made structures. ASTER-GDEM can also be affected by cloud cover, such as very low but dense boundary layer clouds in tropical regions. All those effects are difficult to filter in the raw data products despite large processing and can result in erroneous high elevation topographic data, inducing further large errors in the hypsographic curves.

In order to prevent overestimation of surface water volumes due to high elevation values at the upper edge of the hypsographic curve for some pixels, we proposed a correction method which is thoroughly explained in Section 3.2 of [14] over the Amazon basin. This method mainly consists in calculating for each pixel the standard deviations (STD) of the water volume derived 
from ASTER-GDEM and STRM30-HyMAP hypsographic curves over 5\% flood coverage windows. Standard deviation values are then used as proxies of realistic magnitude of surface water volume changes. Unrealistic variations expressed by high standard deviations (higher than the threshold fixed at $0.4 \mathrm{~km}^{3}$ ) are carefully replaced by a fitter value of the surface water storage based on a simple linear regression analysis using the 10 previous water volume values of the hypsographic curve.
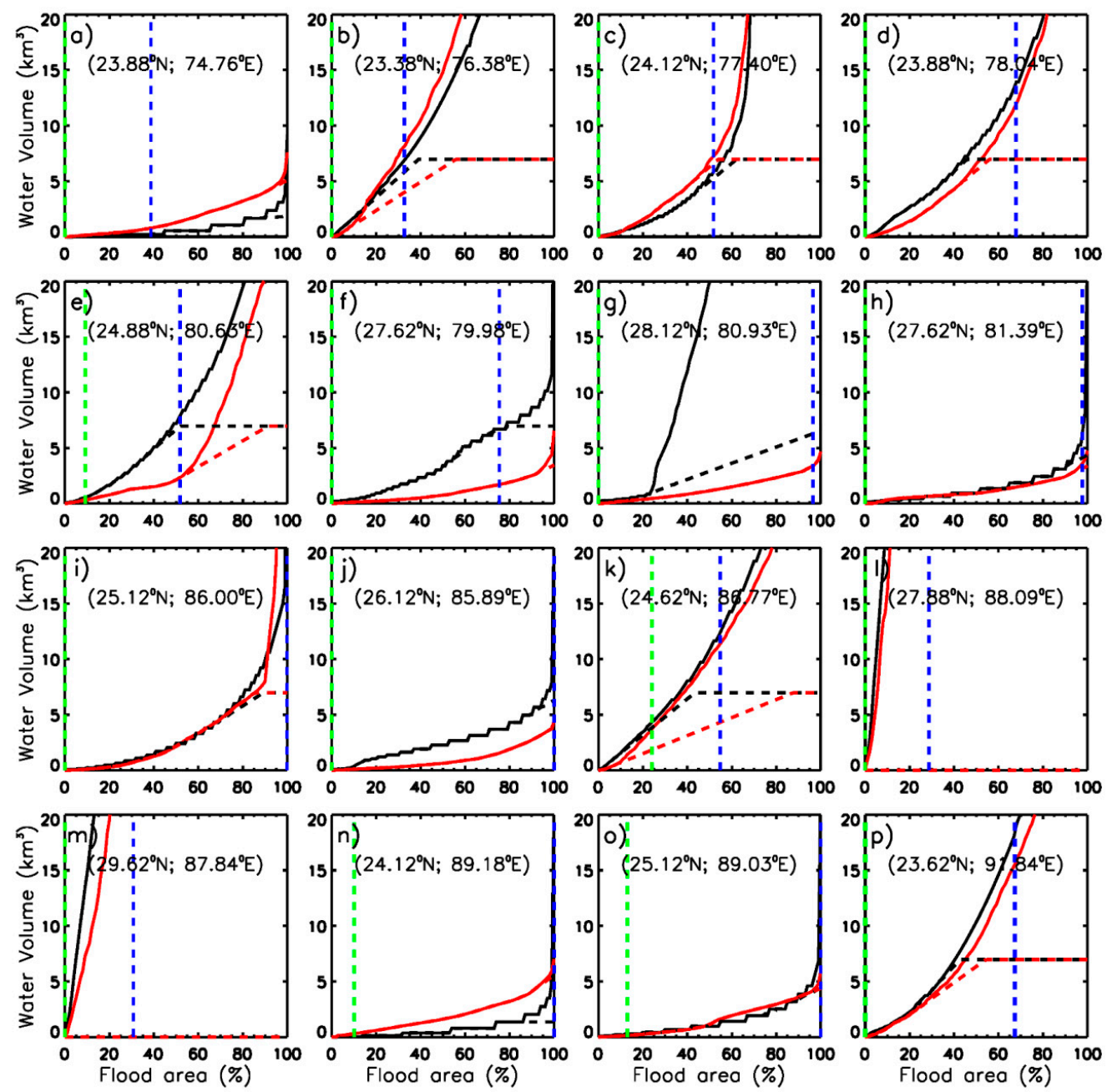

Figure 4. Surface volume profile (equivalent to the hypsographic curve), i.e., the relationship between the surface water storage within each grid cell and the inundated area of a $773 \mathrm{~km}^{2}$ pixel (in percent) for several locations over the GB basin. Red curves are from Advanced Spaceborne Thermal Emission and Reflection Radiometer (ASTER)-Global Digital Elevation Model (GDEM) and black curves from Hydrological Modeling and Analysis Platform (HyMAP)-GDEM. The blue dashed line is the maximum coverage of surface water and the green dashed line is the minimum coverage of surface water observed by GIEMS during the period 1993-2007. The dashed red curves and the dashed black curves represent the hypsographic curves from ASTER-GDEM and HyMAP-GDEM respectively, after corrections are applied (see [14] for details.). (a-p) correspond to 16 different locations in the Ganges-Brahmaputra basin.

\subsection{Time Series of Basin Scale Total Water Storage (TWS)}

The time variations of volume of TWS anomalies from Level-2 GRACE solutions are computed following [51]:

$$
\Delta V_{T W S}(t)=R_{e}^{2} \sum_{j \in S} \Delta h_{t o t}\left(\lambda_{j}, \varphi_{j}, t\right) \cos \left(\varphi_{j}\right) \Delta \lambda \Delta \varphi
$$


where $\Delta h_{t o t}\left(\lambda_{j}, \varphi_{j}, t\right)$ is the anomaly of TWS at time $t$ of the pixel of coordinates $\left(\lambda_{j}, \varphi_{j}\right)$ and $R_{e}$ is the radius of the Earth $(6378 \mathrm{~km})$.

\section{Results and Discussion}

Combining the corrected ASTER-GDEM (and HyMAP) hypsographic curves and the GIEMS satellite-derived observations corrected from MODIS, we can now estimate, for the first time, the long-term Ganges-Brahmaputra SWS and spatio-temporal variations for the period 1993-2007.

Figure 5 shows the spatial distribution of SWS characteristics (annual mean, standard deviation, mean annual maximum, and mean annual amplitude estimated for the study period) for the entire GB basin. Realistic spatial patterns are observed with the upstream pixels characterized by smaller water volumes in contrast with the downstream region. Major river channels are well delineated from the head to the outlet (or the confluence in case of a tributary), as well as the extensive floodplains present along their stream. Following the spatial distribution observed in GIEMS products (Figure 2), both floodplains associated with the river channels in the GB basin and delta plains in southern Bangladesh are well represented. SWS standard deviation (Figure 5b) and mean annual amplitude (Figure 5d) highlight the regions with strong variability such as the Meghna floodplains (between longitudes $90^{\circ} \mathrm{E}$ and $94^{\circ} \mathrm{E}$ and latitudes $22^{\circ} \mathrm{N}$ and $26^{\circ} \mathrm{N}$ ) and the river confluences in Bangladesh that form the Bengal delta.

Figure 6 presents the monthly variations of basin-scale SWS for the 1993-2007 period for the Ganges (a), Brahmaputra (b) and the entire GB system (c). It corresponds to surface water volumes estimated before (green for ASTER and black for HyMAP) and after (blue for ASTER and red for HyMAP) the use of the MODIS inundation mask.

In order to evaluate the present method, our results were compared to SWS variation estimates from [13]. The technique used in the latter study is based on the combination of water extents given by GIEMS and altimetry-based water levels. It should be noted that the technique used by [13] also applies a MODIS mask to the GIEMS dataset. The SWS time series obtained by the present study (ASTER in blue and HyMAP in red) and by [13] (green) are presented in Figure 7 along with GRACE-derived TWS variations (black) over the same period and same geographical locations mentioned above.
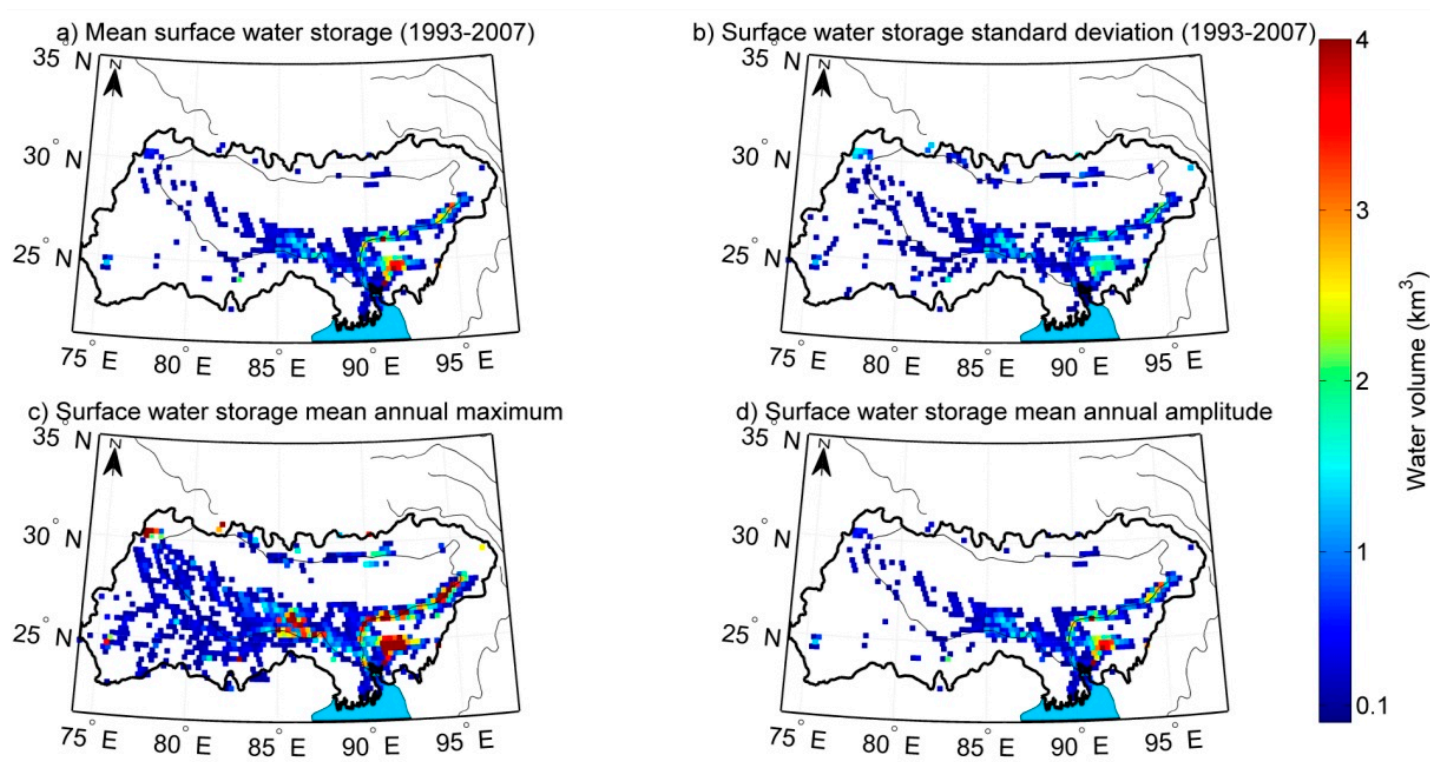

Figure 5. Main characteristics of the surface water storage (SWS) spatial distribution provided by the hypsographic curve approach (GIEMS/ASTER): (a) Mean surface water storage over the 1993-2007 period; (b) Associated standard deviation; (c) Mean annual maximum of SWS; (d) Mean annual amplitudes of SWS. It should be noted that water volumes below $0.1 \mathrm{~km}^{3}$ are not shown in this figure. 
a) Ganges

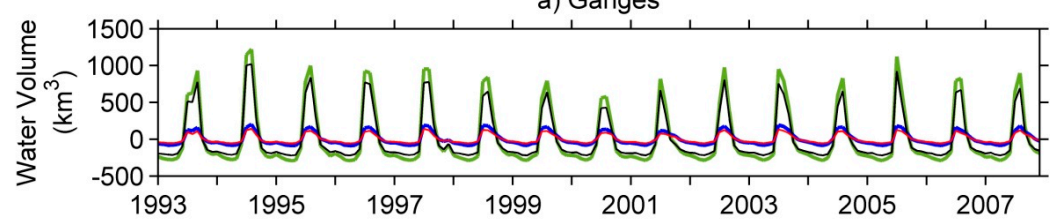

b) Brahmaputra

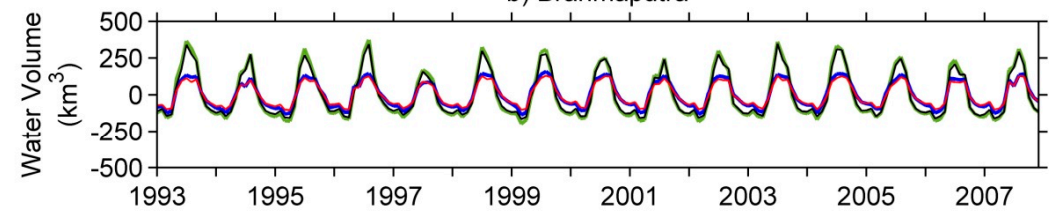

c) Ganges-Brahmaputra

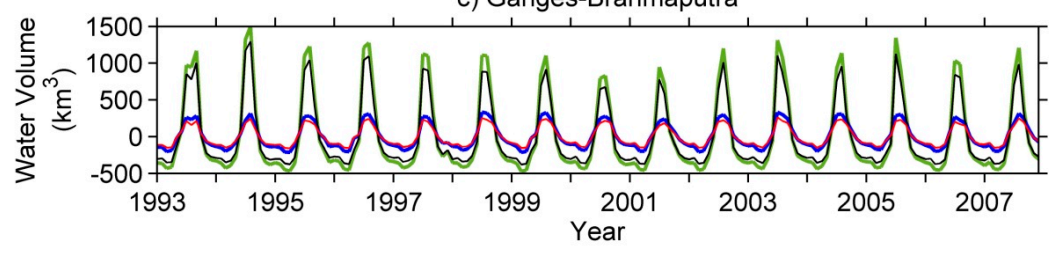

-SWS ASTER —SWS ASTER/MASK — SWS HyMAP — SWS HyMAP/MASK

Figure 6. Monthly mean surface water storage variations for the period 1993-2007 estimated by the combination of GIEMS water extents (before and after the usage of a MODIS mask) and a GDEM (ASTER or HyMAP) over: (a) Ganges; (b) Brahmaputra, and (c) Ganges-Brahmaputra River basins.

The variations of SWS (Figure 6) after the use of the MODIS mask maintain a similar variation pattern (correlation coefficients higher than 0.94 over G, B and GB for ASTER and HyMAP) along with a significant decrease in amplitude. For the entire GB system, SWS ASTER mean amplitude decreases from $\sim 1612 \mathrm{~km}^{3}$ to $\sim 496 \mathrm{~km}^{3}$ and SWS HyMAP mean amplitude decreases from $\sim 1339 \mathrm{~km}^{3}$ to $\sim 378 \mathrm{~km}^{3}$. Mean annual amplitudes estimated using the two techniques (GIEMS-MODIS/GDEM and GIEMS-MODIS/Alt) over G, B and GB are given in Table 1. The magnitude of SWS corrections is higher in the Ganges than the Brahmaputra; this might be the result of relatively higher agricultural coverage in the Ganges basin. These results are consistent with the evaluation of SWS over the GB basin carried out by [13] as shown in Figure 7, giving a SWS mean amplitude of $410 \mathrm{~km}^{3}$ and a SWS/TWS ratio $~ 0.45$. The Pearson correlation coefficient calculated between SWS estimated by the two techniques is higher than 0.95 for the different couples of time series (SWS GIEMS/Alt-SWS GIEMS/ASTER and SWS GIEMS/Alt-SWS GIEMS/HyMAP) over G, B, and GB.

A strong seasonal cycle is observed with maximum surface water volume in August, one month before the TWS peak and a minimum volume in March-April one month before the TWS minima (Figure 7). The maximum lagged correlation coefficient between TWS and the SWS time series (ASTER and HyMAP) is always higher than 0.9, with a lag time of one month. The delayed seasonal phases of TWS relative to SWS can be explained by the lower flow velocities of water in the soil and in groundwater in comparison to the surface water movement, causing recharge and drainage to continue after the maximum and minimum of SWS. In agreement with the results from [13], these new datasets confirm that SWS contributes annually to $\sim 50 \%$ of TWS variations for both river basins. 

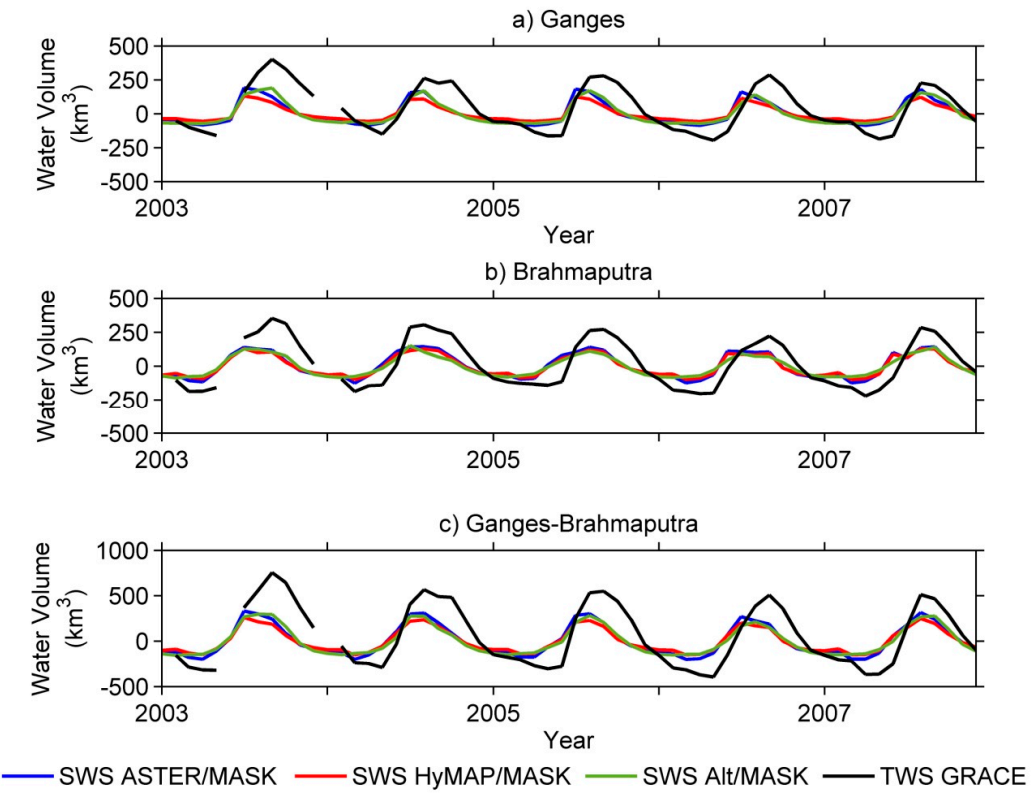

Figure 7. Monthly basin-scale SWS variations estimated using the GIEMS/GDEM approach (blue for ASTER and red for HyMAP), by the GIEMS/Altimetry technique (green) and total water storage (TWS) variations estimated using Gravity Recovery And Climate Experiment (GRACE) for the period 2003-2007 over: (a) Ganges; (b) Brahmaputra, and (c) Ganges-Brahmaputra River basins.

Table 1. Mean annual amplitudes of SWS variations estimated by GIEMS/GDEM and GIEMS/Altimetry techniques over the G, B, and GB system.

\begin{tabular}{cccc}
\hline \multicolumn{4}{c}{ Mean Annual Amplitude $\mathbf{( k m}^{\mathbf{3}} \mathbf{)}$} \\
\hline \multirow{2}{*}{ Basin } & Using GDEM & Using Altimetry \\
Ganges & GIEMS/ASTER & GIEMS/HyMAP & GIEMS/Alt \\
Brahmaputra & 254 & 172 & 300 \\
Ganges-Brahmaputra & 253 & 212 & 250 \\
\hline
\end{tabular}

In the following, SWS estimates are compared and evaluated with two other related hydrological variables: satellite altimeter-derived river discharge measured at Hardinge Bridge and Bahadurabad (see Figure 1 for locations) and basin-scale estimates of precipitation from GPCP. Figures 8 and 9 show the annual variations (a), the mean seasonal cycle (b) and the inter-annual variations (c) of SWS (blue), precipitation (gray), and discharge (red) over the Ganges (Figure 8) and the Brahmaputra (Figure 9) River basins. The normalized anomalies shown in Figures $8 \mathrm{c}$ and $9 \mathrm{c}$ are obtained by removing the mean seasonal cycle of 1993-2007 and normalizing by the corresponding standard deviation. Considering the similarity between SWS obtained by GIEMS/ASTER and GIEMS/HyMAP, only SWS GIEMS/ASTER time series are presented in the figures below.

SWS time series (GIEMS / ASTER and GIEMS/HyMAP) show high consistency (Figures 8a and 9a) with precipitation $(R>0.87)$ and discharge $(R>0.90)$ time series for the period 1993-2007. As shown in Figures 8 and 9, there is no delay between precipitation and SWS at basin scale as intense local rainfall during the annual monsoon results in fast soil saturation followed by quasi-instantaneous inundation of large extents and SWS variations. In contrast, SWS leads discharge by one month in Ganges and Brahmaputra: this time lag corresponds to the residence time of water in floodplains before flowing into the mainstream. The mean seasonal cycle (Figures $8 b$ and $9 b$ ) in the GB watershed shows well the increase in the SWS as a consequence to the wet south-west monsoonal high rainfall rate between June and September. Over the period 2003-2007, there is also a close correspondance between SWS and TWS for both river basins $(R>0.91)$. Maximum cross-correlation coefficients $\left(R_{\max }\right)$ calculated for 
annual and inter-annual variations are given in Table 2 along with the corresponding time lags. Note that correlation coefficients between inter-annual time series of TWS and SWS were not computed due to the short period of observation.

Inter-annual variations shown in Figures $8 c$ and $9 c$, highlight the years when wetter and dryer events take place. For the Ganges River basin, extreme negative anomalies associated to SWS occur in 1993, 1994, 2001 and 2006; as for the Brahmaputra basin, the years 1994, 1997, 2006 and 2007 show significant negative anomalies. High positive anomalies lasting several consecutive months are especially observed in 1998 and 2004 over the Ganges, with many other years over the record showing smaller positive anomalies. The years 1998 and 2004 show strong positive anomalies for the Brahmaputra basin.
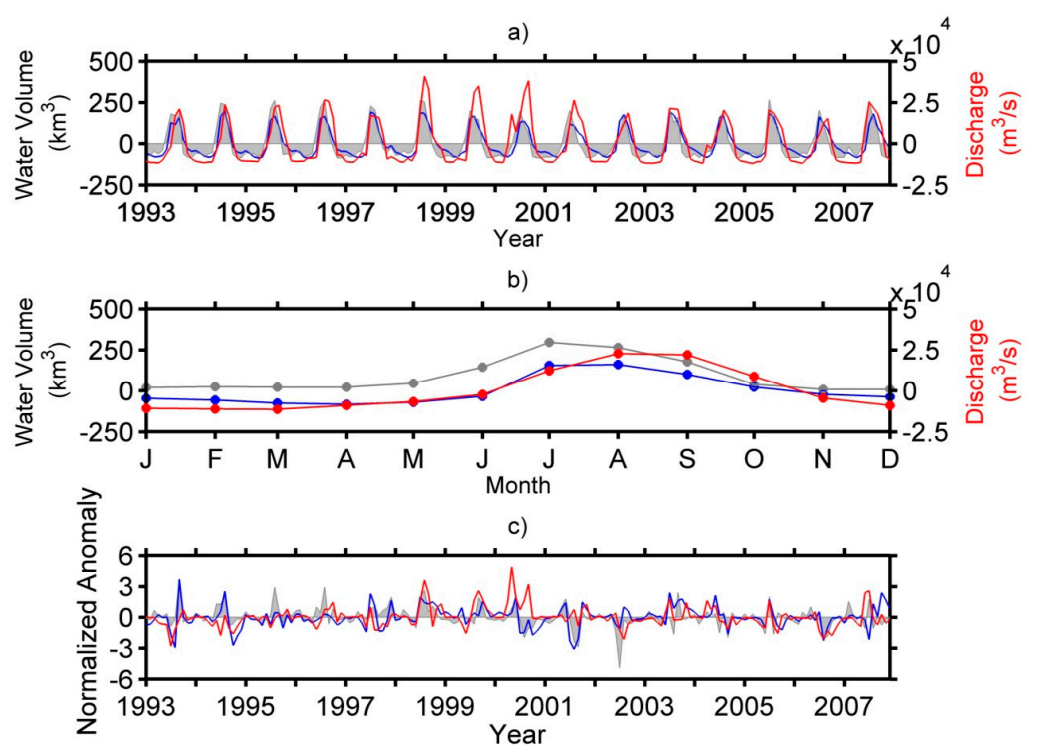

Figure 8. Surface water storage (blue) time series comparison with precipitation (gray) and discharges (red) over the Ganges catchment: (a) Annual variations; (b) Mean seasonal cycle; (c) Inter-annual variations.
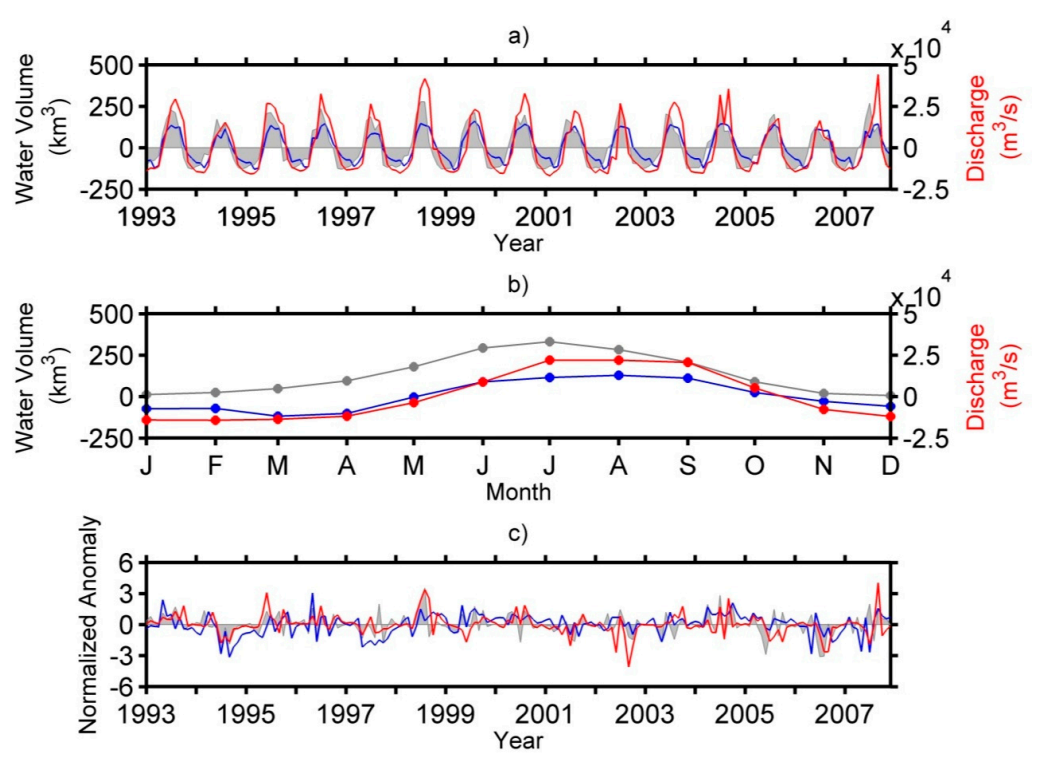

Figure 9. Surface water storage (blue) time series comparison with precipitation (gray) and discharges (red) over the Brahmaputra catchment: (a) Annual variations; (b) Mean seasonal cycle; (c) Inter-annual variations. 
Table 2. Maximum cross correlation $\left(R_{\max }\right)$ coefficients and time lags calculated between SWS time series (GIEMS/ASTER and GIEMS/HyMAP) and the three related hydrological parameters: TWS, discharge and precipitation.

\begin{tabular}{|c|c|c|c|c|}
\hline \multicolumn{5}{|c|}{$R_{\max }$ (Time Lag in Month) } \\
\hline Basin & Technique & Parameter & $\begin{array}{c}\text { Annual Time } \\
\text { Series }\end{array}$ & $\begin{array}{c}\text { Inter-Annual Time } \\
\text { Series }\end{array}$ \\
\hline \multirow{6}{*}{ Ganges } & \multirow{3}{*}{ GIEMS/ASTER } & TWS & $0.91(-1)$ & / \\
\hline & & Discharge & $0.87(0)$ & $0.3(0)$ \\
\hline & & Precipitation & $0.87(0)$ & $0.51(0)$ \\
\hline & \multirow{3}{*}{ GIEMS/HyMAP } & TWS & $0.91(-1)$ & / \\
\hline & & Discharge & $0.86(0)$ & $0.26(0)$ \\
\hline & & Precipitation & $0.88(0)$ & $0.50(0)$ \\
\hline \multirow{6}{*}{ Brahmaputra } & \multirow{3}{*}{ GIEMS/ASTER } & TWS & $0.94(-1)$ & / \\
\hline & & Discharge & $0.90(0)$ & $0.34(0)$ \\
\hline & & Precipitation & $0.89(1)$ & $0.38(0)$ \\
\hline & \multirow{3}{*}{ GIEMS/HyMAP } & TWS & $0.94(-1)$ & / \\
\hline & & Discharge & $0.91(0)$ & $0.38(0)$ \\
\hline & & Precipitation & $0.90(1)$ & $0.33(0)$ \\
\hline
\end{tabular}

In order to further illustrate such drought/flood events in the Ganges-Brahmaputra River system, Figure 10 shows spatio-temporal patterns of SWS for the two contrasted years of 1994 and 1998. Figure 10a-c show the temporal variability of SWS (over the Ganges, the Brahmaputra, and the entire Ganges-Brahmaputra respectively, estimated by GIEMS/ASTER technique) for 1994 and 1998 as compared to their mean seasonal cycle (estimated over the period 1993-2007). For both the Ganges and Brahmaputra basins, SWS estimates in 1998 are larger than the mean seasonal cycle values, especially during the monsoon season. This is in agreement with several past studies that characterized the 1998 monsoon season as extremely "flooded", with for instance $[15,63]$ reporting that during the summer of 1998 over $60 \%$ of Bangladesh was inundated for nearly three months. Figure 10e, showing the spatial distributions of SWS anomalies for July 1998, illustrates well the patterns of these major flood events with large positive anomalies over the entire GB system. On the other hand, it is interesting to note that SWS estimates in 1994, which is characterized as a drought year, are below the mean seasonal cycle only for the Brahmaputra basin as reported in [64]. Nevertheless, Figure 10d shows that major drought patterns are well observed over the Brahmaputra and the main channel of the Ganges. The drought observed over the main Ganges channels is compensated by positive anomalies distributed over the rest of the basin, which diminish the signature of the drought over the entire basin.

This case scenario highlights the importance of the new SWS dataset that helps spatialize large-scale drought/flood patterns. Nevertheless, it should be also noted that when estimating SWS during severe droughts (which involved the low end of the hypsographic curves), the proposed method assumes that we cannot have access to water storage below the minimum values that GIEMS/ASTER and GIEMS/HyMAP can provide. This can be a potential source of uncertainties when estimating the extreme low storage values of exceptional drought years. Indeed, in order to capture correctly the extreme low storage values during droughts, ASTER and SRTM-GDEM should have produced credible elevation data for those periods at the low end of the histograms. Unfortunately, it is not possible at this stage to verify such information.

Investigating the large-scale climate causes of these anomalous drought/flooding events in the Ganges-Brahmaputra is far beyond the scope of this paper, but the new availability of these long-term continuous estimates of SWS will help such future studies. For instance, these new observations are in accordance with the results of [65], which investigate how the occurrence (or co-occurrence) of different climate modes (El-Niño, La Niña and Indian Ocean Dipole (IOD) events) affects the variability of precipitation in the GB basin, as well as the occurrences of major flood and drought events: for 
instance, major droughts, such as the one observed in 1994, are linked to a positive Indian Ocean Dipole (pIOD) mode, whereas major floods, such as the one in 1998 for the entire GB system, might be linked to a negative Indian Ocean Dipole (nIOD) mode.
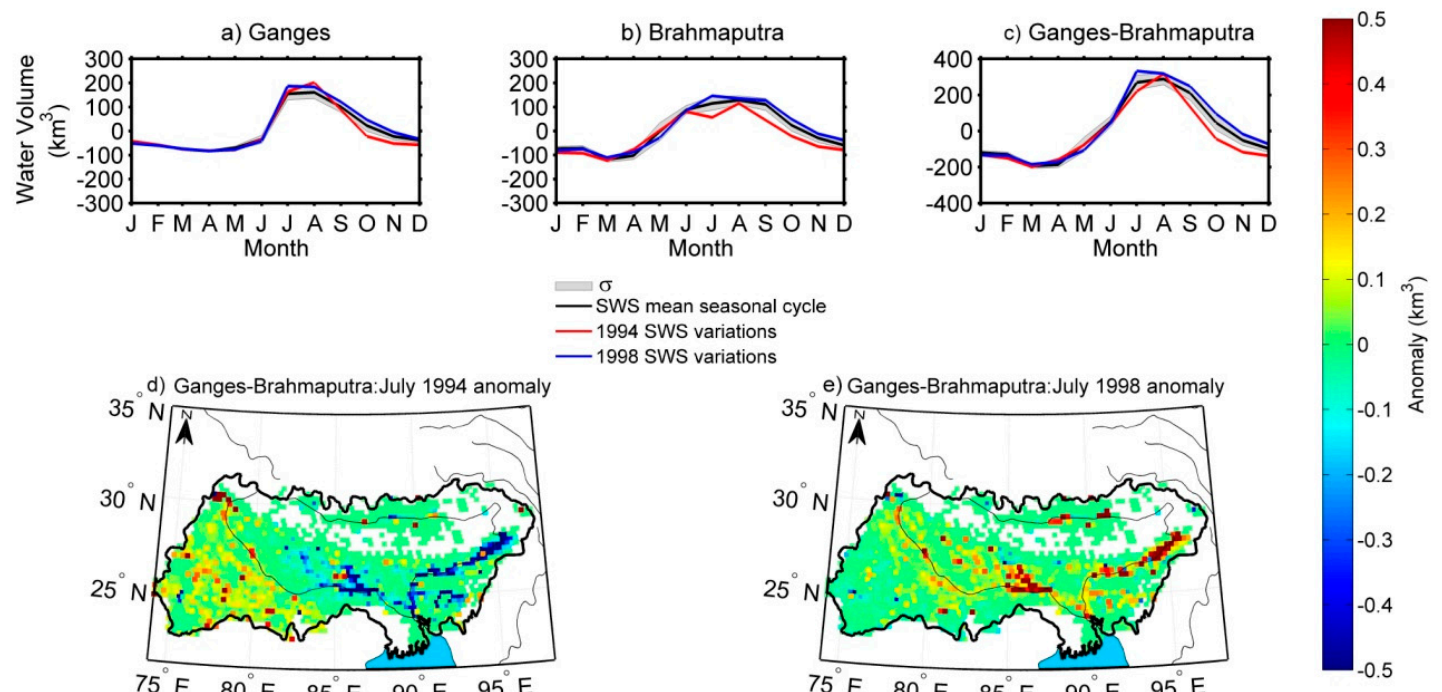

Figure 10. Spatio-temporal variations of SWS estimated by the GIEMS/ASTER technique for the two years of 1994 and 1998: (a-c) show the SWS mean seasonal cycle (black) and its standard deviation (shaded gray) for the 1993-2007 period along with SWS variations for 1994 (red) and 1998 (blue) over the Ganges, the Brahmaputra, and the Ganges-Brahmaputra respectively; (d,e) show the spatial distribution of SWS anomalies over the GB system for July 1994 and July 1998 respectively.

\section{Conclusions}

This study presents an estimation and evaluation of SWS variations over the Ganges-Brahmaputra system between 1993 and 2007. The technique used to determine the water volume variations consists in combining water extents from GIEMS with topographic information extracted from GDEMs (ASTER and HyMAP). It follows the method developed by [14] and previously applied in the Amazon basin. Due to the presence of extensive saturated soils (resulting from intense irrigation practices) in the GB basin, the inundated extent detected using GIEMS was overestimated. A MODIS-based static mask was applied to discriminate between flooded and water saturated soil, providing realistic surface water extent. Our results show realistic spatial distribution of surface water reservoirs over the GB compared with previous estimates based on GIEMS and altimetry-based water levels. Basin integrated time series of SWS (G, B and GB) exhibit strong annual and inter-annual variations. For the entire basin, a mean amplitude of $\sim 496 \mathrm{~km}^{3}$ of SWS is estimated by GIEMS/ASTER while GIEMS/HyMAP gives a mean amplitude of $\sim 378 \mathrm{~km}^{3}$, accounting for $41 \%$ and $51 \%$ of the seasonal amplitude of TWS respectively.

The monthly SWS estimates are evaluated against monthly SWS time series estimated by another technique (GIEMS / Alt) and other related hydrological variables such as satellite altimetry-derived river discharge, precipitation and GRACE-derived TWS. Correlations higher than 0.86 were observed among all variables. Lower correlations are calculated when subtracting the seasonal cycle (between 0.23 and 0.51 ).

In this study, we use ASTER and SRTM-GDEM, which as global satellite-derived DEMs show a series of characteristics, artifacts and anomalies that can cause significant problems or errors when used for hydrological applications $[47,48]$. It includes the influence of vegetation cover, man-made constructions and even errors due to cloud cover, such as very low but dense boundary layer clouds in tropical regions that are difficult to correct. These effects may introduce inaccurate elevation in the DEM with consequences on the hypsographic curve technique that we developed. These issues should 
be investigated in future studies and the future release of the DEM from TerraSAR-X for some key regions, such as the Ganges-Brahmaputra delta, might help to solve some issues.

This new data set provides valuable information on the hydrology of the Indian Sub-Continent. It can be used for a better understanding of the complex relationship between the water cycle, climate variability and human activities, for estimating the sub-surface water storage and discharge to the ocean and their impact on key parameters for oceanography of the Bay of Bengal such as salinity and temperature [65-67] and for the validation of regional/global hydrological models.

This methodology had already been tested in the Amazon basin. The present study shows its validity in a very different environment. As GIEMS and the DEMs are available globally, this study is also a first step towards the development of such a database at the global scale. There is also ongoing work to extend the GIEMS time series from 2007 to present. A consistent global SWS dataset from 1993 to present will play a key role in the definition and development of the future hydrology-oriented satellite missions such as the NASA-CNES SWOT (Surface Water and Ocean Topography) dedicated to surface hydrology $[68,69]$.

Acknowledgments: This work was supported by the Centre National d'Etudes Spatiales (CNES) TOSCA (Terre Solide, Océan, Surfaces Continentales et Atmosphère) and OSTST (Ocean Surface Topography Science Team) grants "Variability of terrestrial freshwater storage in the Tropics from multi-satellite observations" managed by Selma Cherchali and by the Belmont Forum project BAND-AID (ANR-13-JCLI-0002, http:/ / Belmont-BanDAiD.org or http:/ / Belmont-SeaLevel.org) with PI C.K. Shum from Ohio State University. We thank Raffael Maurer for his involvement in processing ASTER-GDEM data during his work at NASA-GISS.

Author Contributions: Fabrice Papa and Frédéric Frappart conceived and designed the experiments; Fabrice Papa, Frédéric Frappart and Catherine Prigent performed the experiments; Fabrice Papa, Frédéric Frappart and Edward Salameh analyzed the data; Catherine Prigent, Filipe Aires, Andreas Güntner, Vuruputur Venugopal, David Labat and Benoit Laignel were involved in the analysis of the results; Edward Salameh, Fabrice Papa and Frédéric Frappart wrote the paper. All authors contributed to the discussion of results and the preparation of the manuscript.

Conflicts of Interest: The authors declare no conflict of interest. The founding sponsors had no role in the design of the study; in the collection, analyses, or interpretation of data; in the writing of the manuscript, and in the decision to publish the results.

\section{References}

1. Chahine, M.T. The hydrological cycle and its influence on climate. Nature 1992, 359, 373-380. [CrossRef]

2. Papa, F.; Prigent, C.; Aires, F.; Jimenez, C.; Rossow, W.B.; Matthews, E. Interannual variability of surface water extent at the global scale, 1993-2004. J. Geophys. Res. 2010, 115, 1-17. [CrossRef]

3. Alsdorf, D.E.; Rodriguez, E.; Lettenmaier, D.P. Measuring surface water from space. Rev. Geophys. 2007, 45, 1-24. [CrossRef]

4. Frappart, F.; Papa, F.; Santos da Silva, J.; Ramillien, G.; Prigent, C.; Seyler, F.; Calmant, S. Surface freshwater storage and dynamics in the Amazon basin during the 2005 exceptional drought. Environ. Res. Lett. 2012, 7 , 044010. [CrossRef]

5. Prigent, C.; Papa, F.; Aires, F.; Jimenez, C.; Rossow, W.B.; Matthews, E. Changes in land surface water dynamics since the 1990s and relation to population pressure. Geophys. Res. Lett. 2012, 39, 2-6. [CrossRef]

6. Prigent, C.; Papa, F.; Aires, F.; Rossow, W.B.; Matthews, E. Global inundation dynamics inferred from multiple satellite observations, 1993-2000. J. Geophys. Res. 2007, 112. [CrossRef]

7. Frappart, F.; Do Minh, K.; L’Hermitte, J.; Cazenave, A.; Ramillien, G.; Le Toan, T.; Mognard-Campbell, N. Water volume change in the lower Mekong from satellite altimetry and imagery data. Geophys. J. Int. 2006, 167, 570-584. [CrossRef]

8. Birkett, C.M. The contribution of TOPEX/POSEIDON to the global monitoring of climatically sensitive lakes. J. Geophys. Res. 1995, 100, 25179-25204. [CrossRef]

9. Frappart, F.; Papa, F.; Famiglietti, J.S.; Prigent, C.; Rossow, W.B.; Seyler, F. Interannual variations of river water storage from a multiple satellite approach: A case study for the Rio Negro River basin. J. Geophys. Res. Atmos. 2008, 113, 1-12. [CrossRef]

10. Frappart, F.; Calmant, S.; Cauhopé, M.; Seyler, F.; Cazenave, A. Preliminary results of ENVISAT RA-2-derived water levels validation over the Amazon basin. Remote Sens. Environ. 2006, 100, 252-264. [CrossRef] 
11. Frappart, F.; Papa, F.; Guntner, A.; Werth, S.; Ramillien, G.; Prigent, C.; Rossow, W.B.; Bonnet, M.P. Interannual variations of the terrestrial water storage in the lower $\mathrm{Ob}^{\prime}$ basin from a multisatellite approach. Hydrol. Earth Syst. Sci. 2010, 14, 2443-2453. [CrossRef]

12. Frappart, F.; Papa, F.; Malbéteau, Y.; Leon, J.G.; Ramillien, G.; Prigent, C.; Seoane, L.; Seyler, F.; Calmant, S. Surface freshwater storage variations in the Orinoco floodplains using multi-satellite observations. Remote Sens. 2015, 7, 89-110. [CrossRef]

13. Papa, F.; Frappart, F.; Malbéteau, Y.; Shamsudduha, M.; Vuruputur, V.; Sekhar, M.; Ramillien, G.; Prigent, C.; Aires, F.; Pandey, R.K.; et al. Satellite-derived surface and sub-surface water storage in the Ganges-Brahmaputra River Basin. J. Hydrol. Reg. Stud. 2015, 4, 15-35. [CrossRef]

14. Papa, F.; Frappart, F.; Guntner, A.; Prigent, C.; Aires, F.; Getirana, A.C.V.; Maurer, R. Surface freshwater storage and variability in the Amazon basin from multi-satellite observations, 1993-2007. J. Geophys. Res. Atmos. 2013, 118, 11951-11965. [CrossRef]

15. Chowdhury, R.; Ward, N. Hydro-meteorological variability in the greater Ganges-Brahmaputra-Meghna basins. Int. J. Climatol. 2004, 24, 1495-1508. [CrossRef]

16. Gain, A.K.; Wada, Y. Assessment of future water scarcity at different spatial and temporal scales of the Brahmaputra River Basin. Water Resour. Manag. 2014, 28, 999-1012. [CrossRef]

17. Winkel, L.; Berg, M.; Amini, M.; Hug, S.J.; Johnson, C.A. Predicting groundwater arsenic contamination in Southeast Asia from surface parameters. Nat. Geosci. 2008, 1, 536-542. [CrossRef]

18. Singh, I.B. The Ganga River. In Large Rivers Geomorphology and Management; Gupta, A., Ed.; John Wiley \& Sons Ltd: Chichester, UK, 2007.

19. Singh, S.K. Erosion and Weathering in the Brahmaputra River System. In Large Rivers Geomorphology and Management; Gupta, A., Ed.; John Wiley \& Sons Ltd: Chichester, UK, 2007.

20. Prigent, C.; Matthews, E.; Aires, F.; Rossow, W.B. Remote sensing of global wetland dynamics with multiple satellite data sets. Geophys. Res. Lett. 2001, 28, 4631-4634. [CrossRef]

21. Papa, F.; Prigent, C.; Durand, F.; Rossow, W.B. Wetland dynamics using a suite of satellite observations: A case study of application and evaluation for the Indian Subcontinent. Geophys. Res. Lett. 2006, 33, 5-8.

22. Prigent, C.; Rossow, W.B.; Matthews, E. Microwave land surface emissivities estimated from SSM/I observations. J. Geophys. Res. 1997, 102, 21867-21890. [CrossRef]

23. Prigent, C.; Aires, F.; Rossow, W.B. Land Surface Microwave Emissivities over the Globe for a Decade. Bull. Am. Meteorol. Soc. 2006, 87, 1573-1584. [CrossRef]

24. Rossow, W.B.; Schiffer, R.A. Advances in Understanding Clouds from ISCCP. Bull. Am. Meteorol. Soc. 1999, 80, 2261-2287. [CrossRef]

25. Kalnay, E.; Kanamitsu, M.; Kistler, R.; Collins, W.; Deaven, D.; Gandin, L. The NCEP/NCAR 40-Year Reanalysis Project. Bull. Am. Meteorol. Soc. 1996, 77, 437-470. [CrossRef]

26. Papa, F.; Guntner, A.; Frappart, F.; Prigent, C.; Rossow, W.B. Variations of surface water extent and water storage in large river basins: A comparison of different global data sources. Geophys. Res. Lett. 2008, 35, L11401. [CrossRef]

27. Papa, F.; Prigent, C.; Rossow, W.B. Ob' River flood inundations from satellite observations: A relationship with winter snow parameters and river runoff. J. Geophys. Res. Atmos. 2007, 112, 1-11. [CrossRef]

28. Papa, F.; Prigent, C.; Rossow, W.B. Monitoring flood and discharge variations in the large siberian rivers from a multi-satellite technique. Surv. Geophys. 2008, 29, 297-317. [CrossRef]

29. Ringeval, B.; De Noblet-Ducoudré, N.; Ciais, P.; Bousquet, P.; Prigent, C.; Papa, F.; Rossow, W.B. An attempt to quantify the impact of changes in wetland extent on methane emissions on the seasonal and interannual time scales. Glob. Biogeochem. Cycles 2010, 24, 1-12. [CrossRef]

30. Bousquet, P.; Ciais, P.; Miller, J.B.; Dlugokencky, E.J.; Hauglustaine, D.A.; Prigent, C.; Van der Werf, G.R.; Peylin, P.; Brunke, E.; Carouge, C.; et al. Contribution of anthropogenic and natural sources to atmospheric methane variability. Nature 2006, 443, 439-443. [CrossRef] [PubMed]

31. Ringeval, B.; Decharme, B.; Piao, S.L.; Ciais, P.; Papa, F.; De Noblet-Ducoudré, N.; Prigent, C.; Friedlingstein, P.; Gouttevin, I.; Koven, C.; et al. Modelling sub-grid wetland in the ORCHIDEE global land surface model: Evaluation against river discharges and remotely sensed data. Geosci. Model Dev. 2012, 5, 941-962. [CrossRef] 
32. Pedinotti, V.; Boone, A.; Decharme, B.; Crétaux, J.F.; Mognard, N.; Panthou, G.; Papa, F.; Tanimoun, B.A. Evaluation of the ISBA-TRIP continental hydrologic system over the Niger basin using in situ and satellite derived datasets. Hydrol. Earth Syst. Sci. 2012, 16, 1745-1773. [CrossRef]

33. Getirana, A.; Boone, A.; Yamazaki, D.; Decharme, B.; Papa, F.; Mognard, N. The Hydrological Modeling and Analysis Platform (HyMAP): Evaluation in the Amazon basin. J. Hydrometeorol. 2012, 13, 1641-1665. [CrossRef]

34. Decharme, B.; Alkama, R.; Papa, F.; Faroux, S.; Douville, H.; Prigent, C. Global off-line evaluation of the ISBA-TRIP flood model. Clim. Dyn. 2012, 38, 1389-1412. [CrossRef]

35. Decharme, B.; Douville, H.; Prigent, C.; Papa, F.; Aires, F. A new river flooding scheme for global climate applications: Off-line evaluation over South America. J. Geophys. Res. Atmos. 2008, 113, 1-11. [CrossRef]

36. Aires, F.; Papa, F.; Prigent, C. A Long-Term, High-Resolution Wetland Dataset over the Amazon Basin, Downscaled from a Multiwavelength Retrieval Using SAR Data. J. Hydrometeorol. 2013, 14, 594-607. [CrossRef]

37. Lehner, B.; Doell, P. Development and validation of a global database of lakes, reservoirs and wetlands. J. Hydrol. 2004, 296, 1-22. [CrossRef]

38. Adam, L.; Döll, P.; Prigent, C.; Papa, F. Global-scale analysis of satellite-derived time series of naturally inundated areas as a basis for floodplain modeling. Adv. Geosci. 2010, 27, 45-50. [CrossRef]

39. Toutin, T. ASTER DEMs for geomatic and geoscientific applications: A review. Int. J. Remote Sens. 2008, 29, 1855-1875. [CrossRef]

40. Abrams, M.; Bailey, B.; Tsu, H.; Hato, M. The ASTER Global DEM. Photogramm. Eng. Remote Sens. 2010, 76, 344-348.

41. Li, P.; Shi, C.; Li, Z.; Muller, J.-P.; Drummond, J.; Li, X.; Li, T.; Li, Y.; Liu, J. Evaluation of ASTER GDEM using GPS benchmarks and SRTM in China. Int. J. Remote Sens. 2013, 34, 1744-1771. [CrossRef]

42. Hirano, A.; Welch, R.; Lang, H. Mapping from ASTER stereo image data: DEM validation and accuracy assessment. ISPRS J. Photogramm. Remote. Sens. 2003, 57, 356-370. [CrossRef]

43. Hayakawa, Y.S.; Oguchi, T.; Lin, Z. Comparison of new and existing global digital elevation models: ASTER G-DEM and SRTM-3. Geophys. Res. Lett. 2008, 35, 1-5. [CrossRef]

44. Fujisada, H.; Bailey, G.B.; Kelly, G.G.; Hara, S.; Abrams, M.J. ASTER DEM performance. IEEE Trans. Geosci. Remote Sens. 2005, 43, 2707-2713. [CrossRef]

45. Tachikawa, T.; Hato, M.; Kaku, M.; Iwasaki, A. The characteristics of ASTER GDEM version 2. In Proceedings of the 2011 IEEE International Geoscience and Remote Sensing Symposium (IGARSS), Vancouver, BC, Canada, 24-29 July 2011; pp. 3657-3660.

46. Farr, T.; Kobrick, M. The shuttle radar topography mission. Eos Trans. AGU 2007. [CrossRef]

47. Yamazaki, D.; Kanae, S.; Kim, H.; Oki, T. A physically based description of floodplain inundation dynamics in a global river routing model. Water Resour. Res. 2011, 47, 1-21. [CrossRef]

48. Yamazaki, D.; Baugh, C.; Bates, P.D.; Kanae, S.; Alsdorf, D.E.; Oki, T. Adjustment of a spaceborne DEM for use in floodplain hydrodynamic modeling. J. Hydrol. 2012, 436, 81-91. [CrossRef]

49. Pavlis, N.K.; Holmes, S.A.; Kenyon, S.C.; Factor, J.K. Erratum: Correction to the development and evaluation of the earth gravitational model 2008 (EGM2008). J. Geophys. Res. Solid Earth 2012, 118, 2633. [CrossRef]

50. Center for Topographic Studies of the Ocean and Hydrosphere. Available online: http:/ /ctoh.legos.obs-mip. fr (accessed on 28 March 2017).

51. Ramillien, G.; Frappart, F.; Cazenave, A.; Güntner, A. Time variations of land water storage from an inversion of 2 years of GRACE geoids. Earth Planet. Sci. Lett. 2005, 235, 283-301. [CrossRef]

52. Landerer, F.W.; Swenson, S.C. Accuracy of scaled GRACE terrestrial water storage estimates. Water Resour. Res. 2012. [CrossRef]

53. Rodell, M.; Famiglietti, J.S. Detectability of variations in continental water storage from satellite observations of the time dependent gravity field. Water Resour. Res. 1999. [CrossRef]

54. Frappart, F.; Ramillien, G.; Maisongrande, P.; Bonnet, M.-P. Denoising satellite gravity signals by Independent Component Analysis. IEEE Geosci. Remote Sens. Lett. 2010, 7, 421-425. [CrossRef]

55. Frappart, F.; Ramillien, G.; Leblanc, M.; Tweed, S.; Bonnet, M.; Maisongrande, P. An independent component analysis filtering approach for estimating continental hydrology in the GRACE gravity data. Remote Sens. Environ. 2011, 115, 187-204. [CrossRef] 
56. Adler, R.F.; Huffman, G.J.; Chang, A.; Ferraro, R.; Xie, P.; Janowiak, J.; Rudolf, B.; Schneider, U.; Curtis, S.; Bolvin, D.; et al. The Version-2 Global Precipitation Climatology Project (GPCP) Monthly Precipitation Analysis (1979-Present). J. Hydrometeorol. 2003, 4, 1147-1167. [CrossRef]

57. Bangladesh Water Development Board. Available online: http:/ / www.bwdb.gov.bd/ (accessed on 28 March 2017).

58. Papa, F.; Biancamaria, S.; Lion, C.; Rossow, W.B. Uncertainties in mean river discharge estimates associated with satellite altimeter temporal sampling intervals: A case study for the annual peak flow in the context of the future SWOT hydrology mission. IEEE Geosci. Remote Sens. Lett. 2012, 9, 569-573. [CrossRef]

59. Dartmouth Flood Observatory. Available online: http://floodobservatory.colorado.edu (accessed on 28 March 2017).

60. Brakenridge, G.R.; Anderson, E. MODIS-based flood detection, mapping, and measurement: The potential for operational hydrological applications. In Transboundary Floods: Reducing the Risks through Flood Management; Marsalek, J., Stancalie, G., Balint, G., Eds.; Springer: Dordrecht, The Netherlands, 2006.

61. Gianinetto, M.; Villa, P.; Lechi, G. Postflood damage evaluation using Landsat TM and ETM+ data integrated with DEM. IEEE Trans. Geosci. Remote Sens. 2006, 44, 236-243. [CrossRef]

62. Frappart, F.; Bourrel, L.; Brodu, N.; Riofrío Salazar, X.; Baup, F.; Darrozes, J.; Pombosa, R. Monitoring of the Spatio-Temporal Dynamics of the Floods in the Guayas Watershed (Ecuadorian Pacific Coast) Using Global Monitoring ENVISAT ASAR Images and Rainfall Data. Water 2017, 9, 12. [CrossRef]

63. Mirza, M.M.Q.; Warrick, R.A.; Ericksen, N.J. The implications of climate change on floods of the Ganges, Brahmaputra and Meghna rivers in Bangladesh. Clim. Chang. 2003, 57, 287-318. [CrossRef]

64. Pervez, M.S.; Henebry, G.M. Spatial and seasonal responses of precipitation in the Ganges and Brahmaputra river basins to ENSO and Indian Ocean dipole modes: Implications for flooding and drought. Nat. Hazards Earth Syst. Sci. 2015, 15, 147-162. [CrossRef]

65. Akhil, V.P.; Durand, F.; Lengaigne, M.; Vialard, J.; Keerthi, M.G.; Gopalakrishna, V.V.; Deltel, C.; Papa, F.; de Boyer Montégut, C. A modeling study of the processes of surface salinity seasonal cycle in the Bay of Bengal. J. Geophys. Res. Ocean. 2014, 119, 3926-3947. [CrossRef]

66. Sengupta, D.; Bharath Raj, G.N.; Ravichandran, M.; Sree Lekha, J.; Papa, F. Near-surface salinity and stratification in the north Bay of Bengal from moored observations. Geophys. Res. Lett. 2016, 43, 4448-4456. [CrossRef]

67. Pant, V.; Girishkumar, M.S.; Udaya Bhaskar, T.V.S.; Ravichandran, M.; Papa, F.; Thangaprakash, V.P. Observed interannual variability of near-surface salinity in the Bay of Bengal. J. Geophys. Res. C Ocean. 2015, 120, 3315-3329. [CrossRef]

68. Prigent, C.; Lettenmaier, D.P.; Aires, F.; Papa, F. Toward a High-Resolution Monitoring of Continental Surface Water Extent and Dynamics, at Global Scale: From GIEMS (Global Inundation Extent from Multi-Satellites) to SWOT (Surface Water Ocean Topography). Surv. Geophys. 2015, 37, 339-355. [CrossRef]

69. Biancamaria, S.; Lettenmaier, D.P.; Pavelsky, T.M. The SWOT Mission and Its Capabilities for Land Hydrology. Surv. Geophys. 2015, 37, 307-337. [CrossRef]

(C) 2017 by the authors. Licensee MDPI, Basel, Switzerland. This article is an open access article distributed under the terms and conditions of the Creative Commons Attribution (CC BY) license (http:/ / creativecommons.org/licenses/by/4.0/). 